\title{
SUFISTIC AND TRANSFORMATIVE PEDAGOGIC VALUES IN SYAIKH SITI JENAR NOVEL BY AGUS SUNYOTO GENETIC STRUCTURALISM
}

\author{
Sugeng Riadi*, Emzir** \\ Fakultas Keguruan dan Ilmu Pendidikan UHAMKA, Indonesia* \\ Language Teaching Study Program of Graduate Program of Universitas Negeri Jakarta, Indonesia** \\ sriadi26@gmail.com* \\ emzir@gmail.com**
}

\begin{abstract}
This research aims to know and understand more deeply about mystical values and transformative pedagogic values in the Syaikh Siti Jenar novel written by Agus Sunyoto. The focus of this study was the intrinsic and extrinsic structure of meaning in the novel. The method applied in this study is content analysis using genetic structure by Lucien Goldmann. The results of the study show a number of sufistic values and transformative pedagogic values. Sufistic values include: repentance, ascetic, indigent, patience, gratitude, pleasure, and trust. While the transformative pedagogic values include altruism, egalitarian, pluralism, and eclectic. The findings of the author's world view includes figures deconstruction of the teachings of Syaikh Siti Jenar, cultural missionary endeavor, the concept of superhuman, mystical literature, and literary history.
\end{abstract}

Keywords: novel, genetic structure, mystical values, transformative pedagogic values.

Novel is one literary genres as a manifestation of contemplation and inner struggle of the writer, especially, about dialectic life of human being. In another word, literature tries to explore the deepest part of human soul. This exploration is possible due to the flexibility and elasticity characteristics always adhered to literary works. Therefore, literature is able to go through space and time, which is impossible to do by other fields of knowledge. Nevertheless, literature is not a vacuum space. Literature is rich with values and messages that can be the source of inspiration about wisdom values.

Furthermore, the pattern of Indonesian novels extensively absorbs various values, such as, social values, religious values, political values, etc. One of the values is sufistic values (tasawwuf), which becomes the source of inspiration for most Indonesian writers. It is because sufism (tasawwuf) is one of Islamic teachings which mostly attracts the interest of Indonesian writers for a long time. In 2000s, literary works with sufistic issues reappeared. One of them is a novel entitled Syaikh Siti Jenar by Agus Sunyoto.

Generally, sufistic literary works try to reveal various kinds of spiritual experience of a sufi in the journey of experiencing and finding divine truth. In every step of spiritual journey and the finding effort, a writer tries to interpret the meaning of soul condition and spiritual events they experience, and then tries to express the understanding and interpretation as an aesthetic expression of literature. The message given is also quite clear, namely, to bring enlightenment for their readers as the literary work contains educative values. Thus, the discussion of Syaikh Siti Jenar novel is important to do, to understand more deeply about the values performed by 
main character in order for practice of the teaching and transformation. It is believed that sufistic literary works, especially in form of a novel, always bring universal values which stay relevant because they are timeless and not limited by space.

In the context of literary learning context, for example, sufistic literary works especially Syaikh Siti Jenar novel by Agus Sunyoto, it is rich in didactic values which can be used as an ethical foundation to strengthen character building. It is because there are many teachings and behaviors from the characters emphasizing character with aspects, such as: modesty, honesty, patience, submission, determination, life learning, and the like which are the results of developing sufistic values seen in characterization of the characters.

The sufistic values, in the eyes of the researcher, also have relevance to transformative pedagogy. Transformative pedagogy is a new generation pedagogy science which brings the transformation of shape and character, not only for students but also for teachers. As a new generation of education science, transformative pedagogy has more open characteristic towards the development of era because there is a continuous social change. The social change causes an implication on the development of learning concepts with the orientation on the development of individual to be independent and meaningful human being in adaptation to their era (Pudjosumedi and Riadi, 2012: 42).

The relationship between literature and character building is explained by Moody. According to Moody, in addition to giving language skill, improving cultural knowledge, developing creation and appreciation, it also supports character building (Rudy, 2010:801). Moody’s perspective is also supported by Oemarjati that literature teaching is essentially a process of enlightening inner heart, enriching experience, and character development (Oemarjati, 2012:142). There is a strong relationship between literature and character building as explained by both literature experts, yet, it has not given awareness to the society about the role of literature in character building. One of obstacles in literature learning according to Oemarjati is the reluctance of the students to read. Meanwhile, Atar Semi explains that low quality of literature teaching is due to various factors, such as: curricula, learning facility, and teacher. From the three factors, teacher is the dominant factor. The appearing factor is when teacher has less mastery of literature teaching mastery. Strategy of literature teaching is studied as it can create a learning condition supporting the purpose of learning. Not only that, teaching strategy can motivate students to actively participate in learning activity if it is used well by teacher (Semi, 2002:134).

Based on the background of study, this study is aimed to reveal the sufistic and pedagogic transformative values in a novel entitled Syaikh Siti Jenar by Agus Sunyoto. With the expectation towards those explained values, it is hoped to give contribution for literature learning in general and character building, specifically.

\section{METHOD}

This research is a literature based research, which uses the main source from Syaikh Siti Jenar novel by Agus Sunyoto, and other books related to the novel. The method used in this study is qualitative method with content analysis. 
The approach used in this research is genetic structural approach with the data analisis prosedure explain the data, data collecting procedure, and data analysis prosedure of this study. following steps: (1) reading the novel intensively, (2) analyzing novel's structure, (3) identifying sufistic and pedagogic transformative values, and (4) drawing a conclusion.

\section{RESULTS AND DISCUSSION}

\section{Structure of Syaikh Siti Jenar Novel}

The story used by the writer in this novel has two plots namely flashback plot and chronology plot. The use of two plots is aimed by the writer to give attraction and curiosity so that readers want to read further about Abdul Jalil character in the novel. Therefore, with such plot, reader intensely keeps their focus to find out the end of the story. Because of chronology plot, reader can easily guess the end of the story.

Meanwhile, there are relatively many and various characters in the story of Syaikh Siti Jenar. As in other stories, the characters of this novel consists of protagonist, antagonist, subordinate, and entertaining characters. Variety of characters is an effort to give interesting effect in the narration.

The protagonist character that becomes the central character in this novel is Abdul Jalil or is well known as Syaikh Siti Jenar. Written as protagonist character by the writer, Abdul Jalil is a figure who brings social cultural change for Javanese society whom in that era was dominated by Hinduism-Buddhism culture to be Islamic society relying on Tauhid.

In line with his role as a spiritual teacher, Abdul Jalil is seen as someone with wisdom, firmness, egalitarian, and wide insight. It happens because Abdul Jalil character as a spiritual teacher, by the narrator, is portrayed as facing difficulties. There are many challenges and trials faced by Abdul Jalil in propagating Islam in Java.

Characters in Syaikh Siti Jenar novels are written using dramatic technique or method. This novel also uses analytic technique, appearance method, or indirect method, which describes a character through mind, conversation, behavior, physical appearance and the description of environment (Nurgiyantoro, 1998: 198).

Syaikh Siti Jenar novel has various settings of time, place, and social background. Setting of time gives explanation about the era of the story. Setting of place can show the location where the story happens. While social setting describes the condition of society in Syaikh Siti Jenar novel.

As a novel with religion and socio-cultural renewal, the theme contained in Syaikh Siti Jenar novel by Agus Sunyoto gives inclusive religious meaning which offers a tauhid perspective presented in Javanese culture which is rich in syncretic and ecletic nuance. It is shown in the messages delivered by Abdul Jalil character both in dialog and messages represented by other characters.

The strength of writer in narrating the theme is by keeping presenting the character, even he becomes superhuman, he keeps himself on the ground as a commoner. Therefore, the messages to deliver are still relevant. Even though the novel takes the setting of $15^{\text {th }}$ century and the beginning of $16^{\text {th }}$ century, the concept of superhuman offered can be realized in our current social and cultural life. 


\section{Sufistic Values in Syaikh Siti Jenar Novel}

The dominant sufistic values in this novel consist of seven values, the first value is taubat (regret of committing a sin). In this novel, the meaning of taubat by the writer is given explicitly and implicitly. The meaning of taubat can be defined as performing Allah's orders and leave prohibitions of Allah. For a salik (spiritual man), it is important to be close to Allah. That is why taubat is a facility to purify the soul and by most Sufism experts is considered an early foundation or basic for a salik to have a spiritual journey to the next maqam or stage which is higher.

Second, is zuhud (ascetic). Ascetic life is a dominant sufistic value in sufism. Just like taubat, the purpose of zuhud is to purify the soul from worldly influence. Ascetic life does not mean to hate material world, but not to be influenced by it. The measure of zuhud is not in the amount of material, but in the stance (Ali, 2005: 54).

The suggestion of ascetic life in this novel is taught in a big deal by Abdul Jalil to his students and his surrounding society, in order to suggest them that as human being, they do not live extravagantly. In teaching ascetic life, Abdul Jalil does not only rely on the theory but he practices ascetic life in his whole life. The practice of ascetic life by Abdul Jalil basically follows the example of ascetic life practice by the Prophet Muhammad Saw. and his four best friends in his whole life. Therefore, Abdul Jalil suggests his students to live an ascetic life as practiced by the Prophet Muhammad Saw and his best friends.

Third is fakir. Fakir according to Abdul Hadi is a spiritual stage which one can achieve after fanaa in the nature of the highest Existence. By quoting Ibn alJalla, relating the soul of fakir with self awareness that one does not have anything because everything belongs to God. This self awareness makes a fakir really prioritizes interest of the people above personal interest, even though he is in hardship (Hadi, 2012: 39). In this novel, the main character Abdul Jalil, as a spiritual teacher, lives a fakir life as a malamit. Malamit is someone who hides his spiritual perfection in a lowly appearance.

Fourth is patience. Patient character is one of four doors that must be passed by Abdul Jalil to go The Existence. The other doors are letting go personal ego, faithful, and submissive. Without going through the four doors, in writer's opinion, the journey to come to Allah cannot be achieved. Therefore, there is no other choice but to go through the four doors. To handle the obstacle, patient character is needed. Patient character is very important to manage desires in human being. Patient character is similar to the endurance towards misfortunes in facing all trials in order to focus on the purpose. By sufis, patient character is often defined as half of faith, and the other half is gratefulness.

Fifth, gratefulness. The value of gratefulness in this novel is not described explicitly but delivered implicitly. And the value of gratefulness which is delivered implicitly is related to Abdul Jalil's effort to share what he has more to the needy. Abdul Jalil believes that what he has more is the blessing from Allah. That is why he serenades gratefulness and laudation in the open nature as the gratefulness to Allah Swt, who has given abundance of blessing and mercy. Gratefulness is strongly related to faith and observance, thus, gratefulness by ulema is seen as half of faith, while patience is the other half (Gulen, 2014: 182).

Sixth, sincerity. Basically, sincerity is a blessing from Allah of which cause depends on human's willingness. Therefore, nobody will achieve sincerity, unless with the depth of faith, determination in good deeds, and awareness to do good deeds, 
which in their journey will form the attitude of tawakal, taslim, and tafwidh. Therefore, the achievement of sincerity is so difficult that Allah never gives the order directly, but Allah gives the messages, suggestions, and compliments on those who successfully achieve the degree of sincerity and elevate their position (Ibid, 200).

And seventh, tawakal. Tawakal is a highest maqam or position to achieve the makrifat. That is why tawakal according to Al-Ghazali is often seen as the result of tauhid. In another word, tauhid functions as a foundation or basic of tawakal. Tawakal is relying our heart to Allah by believing in Allah wholefully, with the awareness to escape from any other power supervision or sources. If self submission and total belief are not achieved, a believer cannot be considered to have tawakal quality (Ibid, 136). In this novel, the values of tawakal are implemented by Abdul Jalil, both as a salik and a spiritual teacher. One of examples of tawakkal value is when Abdul Jalil leaves his child and wife to perform a duty as a spiritual teacher in Nusa Java.

Sufistic values can give contribution to the spiritual competence or inner competence which relies on esoteric dimension.

\section{The values of transformative pedagogy on Novel of Syaikh Siti Jenar}

There are at least four values of transformative pedagogy on this novel, first in the value of Altruist. Altenisan is the character to devote the welfare of others, giving attention to people's prosperity without having self-importance, it is the outcome of spiritual implementation from ascetic and destitute practice. Altruism character is the opposite of selfishness which only upholds self-importance. An attitude that does not imply self-centered as a negation of selfishness, in fact it is a core value which advocated by many traditions even religions.

On this novel, it can be found the altruism values wre performed by Abdul Jalil as the main character. For example, when Abdul Jalil gave money to the poor people in Baghdad at night. And sacrificed himself by establishing several arenas that could be risky to degrade his noble and prosperity and his kin. Altruism, in sufism context, has positive meaning seen from Abdul Jalil's way of life that is as an effort to enlighten the inner-being from negative character and greed. Moreover, altruism can be defined as martyr implementation to overcome self-importance over people's sake that can be regarded as more noble. Altruism refers to approach more direct to God (qurb).

Second is equality. In Abdul Jalil perception, God regards men are equal which the difference only their piety. Abdul Jalil showed Equality because he followed the way of life of Prophet Mohammad when Prophet Mohammad was never seen to disgrace Bilal as a slave and to honor Utsman as a nobleman at the time of Islam. According to Abdul Jalil, he said that he implemented equality because he learned from Prophet Mohammad who taught equality which basically men are equal in spite of their skin color, family-kinship, wealthy and position, at most difference only from their piety.

Third is pluralism. Pluralism or diverse cultures also enlightens the values of transformative pedagogy which driven by Abdul Jalil. The concept of pluralism refers to sufism doctrine which is well-known by the unity of religion (wahdat aladyan). Many implementations of pluralism values can be found on this novel thus regarded as Abdul Jalil's way of life, even though his teaching and counsel to his 
students and companions. The teaching of pluralism which applied by Abdul Jalil is the representation in al Quran chapter Al-Hujurat (49: verse 13).

Fourth is eclectic. Eclectic values that shown by Abdul Jalil is a representation of transformative pedagogy principle which pertaining to the concept of human as a learner. As a learner, human does not restrain himself from attaining horizon of knowledge but he learns from many things as long as it gives benefits. This concept relates to the principle of learning capability. So people can study not only from formal education but also informal or even non-formal education.

Seen from education method which contains the transformative pedagogy values, actually the writer is eager to explain that the education values in Al-Quran and the way of life of Prophet Mohammad then been followed by Abdul Jalil have universal characteristic. Those values are very relevant to be practiced nowadays and in future. The values of transformative pedagogy can be used as the method of learning optimizing the democracy spirit and developing a character who tolerant and has big drive to learn for students and their teachers.

\section{CONCLUSION}

As a novel that contains the teachings and ideas of social reformation, in the context of genetic structuralism, this novel can be grouped into novel containing sufistic spiritual values (sufi) and education (pedagogy).

Sufi values were presented in the spiritual journey towards gnosis, providing spiritual competence quality in Abdul Jalil himself. Hence with his spiritual competence, he becomes a superhuman. With this spiritual competence-based, Abdul Jalil carried out teachings as well as social and religious reformation. In educational praxis, sufistic values can be used as a mean of character education which orientation is the spiritual competence improvement which are reciprocal, for both teachers and students.

Where as the transformative pedagogic values in this novel are implications which were born from sufistic values-based educational praxis; such educational praxis in turn gives girth to education that produce learners who have good values (perfect man). In the context of character education-oriented literary learning, in the perspective of genetic structuralism, it is very relevant because through the main character, either in the form of the teachings and ideas of reformation that are conducted within the reformation of religious and social, it can provide inspiration and insight for readers.

Sufistic values and transformative pedagogic values contribute to the development of sufistic-based teachers' education with the focus on developing spiritual competence in the teachers and students (sufistic pedagogic). Sufistic values education contributes to the strengthening of the inner dimensions which the output is in the spiritual competence. While transformative pedagogic values education is a learning model that gives contribution for the birth of the cultural relation of teachers-students which is personal, holistic, and inclusive.

\section{REFERENCES}

Ali, Yunasril. 2005. Pilar-Pilar Tasawuf. Jakarta: Kalam Mulia. 
Audah. Ali. 1999. Dari Khazanah Dunia Islam. Jakarta: Pustaka Firdaus

Budianta, Melani, et. al. 2003. Membaca Sastra. Magelang: Indonesia Tera.

Burchkhardt, Titus.1984. Mengenal Ajaran Kaum Sufi. Terj. Azyumardi Azra. Jakarta: Pustaka Jaya.

Chodjim, Achmad. 2013. Syekh Siti Jenar: Makrifat Kasunyatan I. Jakarta: Serambi.

Damono, Sapardi Djoko. 1984. Sosiologi Sastra: Sebuah Pengantar Ringkas. Jakarta: Pusat Pembinaan dan Pengembangan Bahasa Depdikbud.

Forster, E.M 1985. Aspect of The Novel. London: Penguin Books.

Goldman., Lucien. 1977. Towards a Sociology of The Novel. London: Tavistock Publication.

Gulen, Muhammad Fethullah. 2014. Tasawuf untuk Kita Semua. Terj. Fuad Syaifudin Nur. (Jakarta: Republika).

Hadi WM, Abdul. 2000. Islam Cakrawala Estetik dan Budaya. Jakarta: Pustaka Firdaus.

. 2011. “Gagasan Faqr dan Fana’ dalam Tasawuf Hamzah Fansuri dan M. Iqbal” dalam Jurnal Tasawuf. Volume 1, Nomor 2, Juli 2012. Jakarta: Pusat Kajian Buya Hamka-Uhamka.

1991. Sastra Sufi: Sebuah Antologi. Jakarta: Pustaka Firdaus.

. 1999. Kembali Ke Akar Kembali Ke Sumber: Esai-Esai Sastra Profetik dan Sufistik. Jakarta: Pustaka Firdaus.

Hamzah, Moch. 2008. “Dimensi Sufistik dalam kumpulan Cerpen karya Zaini”. Disertasi. Tidak diterbitkan.

Hun, Koh Young. 2012. “Sastra dan Sejarah dalam Dunia Pengkaryaan Pramoedya Ananta Toer”. Jurnal Kritik. No. 3, 2012.

Iswanto.2001. "Penelitian Sastra dalam Perspektif Strukturalisme Genetik" dalam Metodologi Penelitian Sastra, Ed. Jabrohim. Yogyakarta: Hanindita.

Jamil. HM. 2013. Akhlak Tasawuf. Ciputat: Referensi.

Mohammad, Goenawan. 1982. "Posisi Sastra Keagamaan Kita Dewasa Ini” dalam Sejumlah Masalah Sastra. Editor Satyagraha Hoerip. Jakarta: Pustaka Sinar Harapan.

Mulder, Niels. 2011. Mistisisme Jawa Ideologi di Indonesia. Yogyakarta: LKIS. 
Noer, Kautsar Azhari. 2002. Tasawuf Perenial. Jakarta: Serambi.

Nurgiyantoro, Burhan. 1995. Teori Pengkajian Fiksi. Yogyakarta: Gajah Mada University Press.

Pudjosumedi dan Sugeng Riadi. 2013. Pengantar Pedagogik Transformatif. Jakarta: Uhamka Press.

Rahmanto, B. 1988. Metode Pengajaran Sastra . Yogyakarta: Kanisius.

Ratna, Nyoman Kutha. 2009. Paradigma Sosiologi Sastra. Yogyakarta: Pustaka Pelajar

Ratna, Nyoman Kutha. 2011. Teori, Metode, dan Teknik Penelitian Sastra. Yogyakarta: Pustaka Pelajar.

Schimmel, Annemarie. 2000. Dimensi Mistik dalam Islam. Terjemahan Sapardi Djoko Damono, dkk. Jakarta: Pustaka Firdaus.

Saraswati, Ekarini. 2003. Sosiologi Sastra. Malang: UMM Press.

Semi, Atar. 1993. Anatomi Sastra. Padang: Angkasa Raya.

Sudjiman, Panuti. 1988. Memahami Cerita Rekaan. Bandung: Pustaka Jaya.

Sunyoto, Agus. 2003. Syaikh Siti Jenar. Jilid 1. Jakarta: LKIS.

Sunyoto, Agus. 2008. Syaikh Siti Jenar. Jilid 2. Jakarta: LKIS.

Sunyoto, Agus. 2008. Syaikh Siti Jenar. Jilid 3. Jakarta: LKIS.

Sunyoto, Agus. 2003. Syaikh Siti Jenar. Jilid 4. Jakarta: LKIS.

Sunyoto, Agus. 2007. Syaikh Siti Jenar. Jilid 5. Jakarta: LKIS.

Sunyoto, Agus. 2008. Syaikh Siti Jenar. Jilid 6. Jakarta: LKIS.

Sunyoto, Agus. 2006. Syaikh Siti Jenar. Jilid 7. Jakarta: LKIS.

Taftazani, Abu Al-Wafa’ al-Ghanimi. Sufi dari Zaman ke Zaman: Suatu Pengantar tentang Tasawuf. Bandung: Pustaka.

Teba, Sudirman. 2003. Syaikh Siti Jenar: Pengaruh Tasawuf Al-Hallaj di Jawa. Jakarta: Pustaka Hidayah.

Tilaar, HAR. 2002. Perubahan Sosial dan Pendidikan: Pengantar Pedagogik Transformatif untuk Indonesia. Jakarta: Grasindo. 